\title{
Nannobiostratigrphy of Shiranish Formation in Balad Well No. 8, Northern Baghdad, Iraq
}

\author{
Omar A. Al-Badrani Eman N. Al-Assaf \\ Department of Geology \\ College of Science \\ University of Mosul
}

(Received 22/3/2010, Accepted 30/6/2010)

\begin{abstract}
Eight samples of Shiranish Formation were obtained from Balad well No. 8, (northern Baghdad) central Iraq. Details investigated carried out identify calcareous nannofossils, where identified sixteen species; eleven descried from other region and five left under open name because of lack of material or rare of samples, On the basis of stratigraphic distribution of the species, two biozones proposed these are :

\section{2- Reinhardites levis Interval Biozone(CC24)}

\section{1- Tranolithus phacelosus Interval Biozone(CC23b)}

The proposed biozones correlated with others calcareous nannofossils biozones from regional schemes led to conclusion that the age of Shiranish Formation in studied section Early Maastrichtian.

$$
\begin{aligned}
& \text { الطباقية الحياتية لمتحجرات النانو الكلسية لتكوين شرانش في بئر بلد ^، }
\end{aligned}
$$

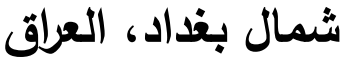

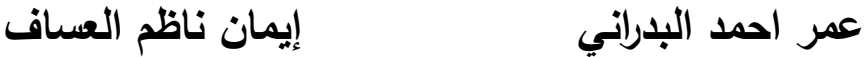

$$
\begin{aligned}
& \text { قسم علوم الأرض كل } \\
& \text { كلية العلوم } \\
& \text { جامعة الموصل } \\
& \text { الملخص } \\
& \text { درست ثمانية نماذج من تكوين شرانش في بئر بلد ^ ( شمال بغداد) وسط العراق. تم وصف ستة }
\end{aligned}
$$

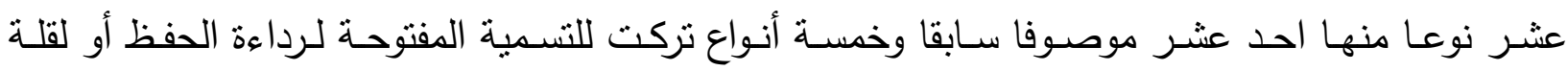

$$
\begin{aligned}
& \text { العينات، وبالاعتماد على التوزيع الطباقي لهذه الحشود تم تحديد نطاقين حياتيين وهما: }
\end{aligned}
$$




\section{2- Reinhardites levis Interval Biozone(CC24)}

\section{1- Tranolithus phacelosus Interval Biozone(CC23b)}

$$
\text { قيد الدراسة مضاهاة الانطقة المحددة مع دراسات إقليمية قادت إلى الاستنتاج بان عمر تكوين شرانش في المقطع }
$$

\section{INTRODUCTION}

Shiranish Formation is the most important rock unit throughout the upper Cretaceous of north Iraq. It's type section is first described by Henson, 1940 (cited in Bellen et al., 1959) lies at Shiranish Islam Village near Zakho City, reaches about 228 meters in thickness. It consists mainly of marl and marly limestone representing off shore, open sea sediment of the Late CampanianMaastrichtian age on the basis of the foraminiferal assemblages contents.

\section{MATERIALS}

The studied section situated in the unstable shelf (Buday and Jassim,1987) Fig. 1, Shiranish Formation is recorded from well Balad No. 8, between (1607.5-1652.5 meter depths) about 45 meters thickness, consist mainly of marly limestone, Eight samples were investigated to identify the nannofossils species.

\section{Systematic Paleontology}

Kingdom Protista

Division Chrysophyta

Class Coccolithophyceae

Family Arkhangelskiellaceae Bukry, 1969

Genus Arkhangelskilla Vekshina, 1959

Type species : Arkhangelskilla cymbiformis Vekshina, 1959

\section{Arkhangelskilla cymbiformis Vekshina, 1959}

Pl. 1, Fig. 1

1959 Arkhangelskilla cymbiformis Vekshina; Sniggims, Vol. 2, P. 66, P1. 2, Fig. 3 a, b.

1968 Arkhangelskilla cymbiformis Vekshina ;Gartner; Univ. Kans. Paleont. Contrib., P. 38, Pl. 1, Fig. 1-4, Pl. 6, Fig. 1a-c.

1985 Arkhangelskilla cymbiformis Vekshina; Perch-Nielsen; Plankton Stratigraphy, P. 354.

Description: Heterococcoliths, placolith coccoliths with central area spanned by axial crosses and grills, or filled by a perforate plate divided by axial sutures. The shields are typically bright in cross polarized light. 1-2 distal shield cycles; bright, unicycle LM image although darker towards outer edge. The central area is 
continuous with the fourth tier and is divided into four quadrants by sutures lines subparallel to major and minor axes of the ellipse.

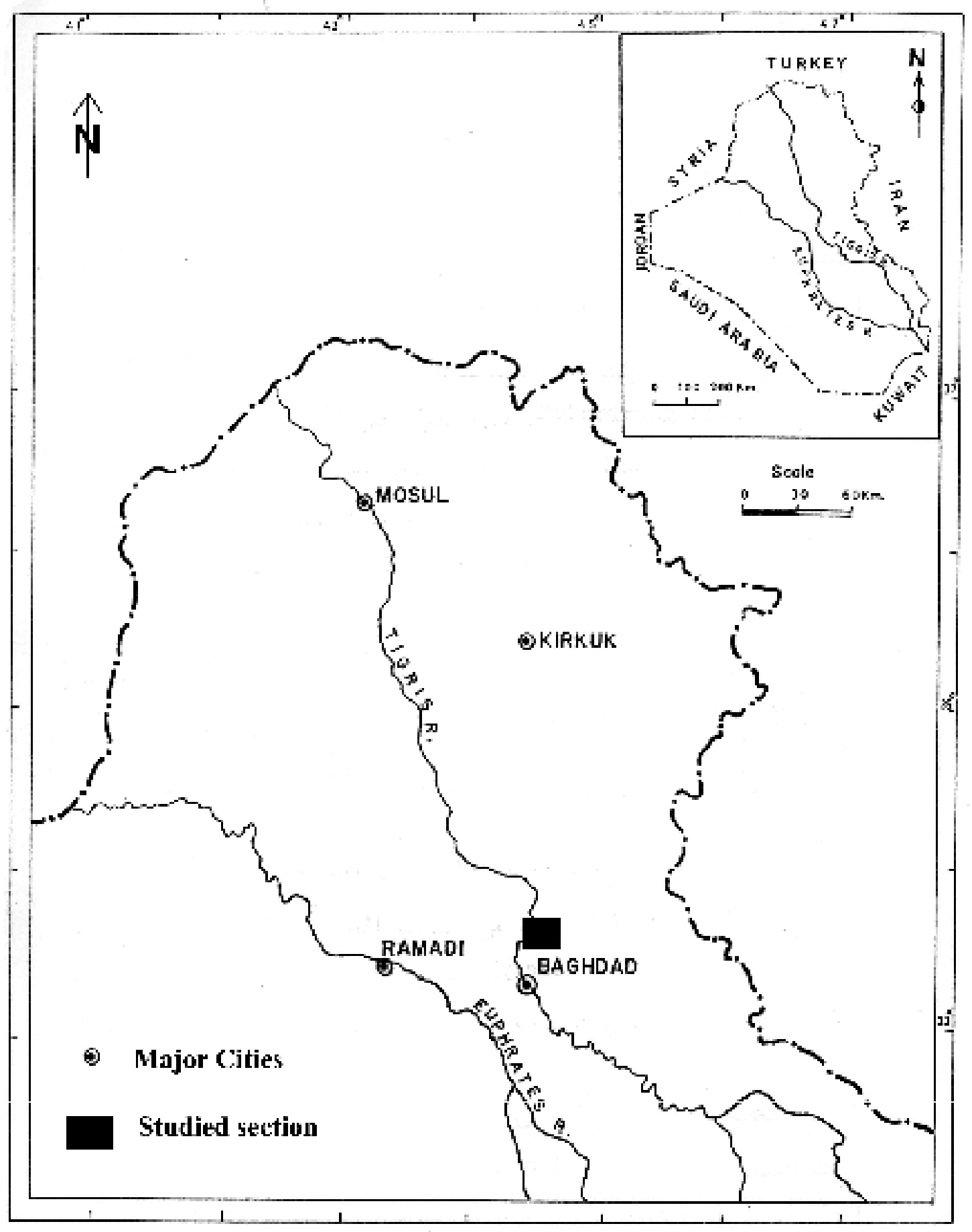

Fig. 1: Location Map of Studied Section. 
Occurrences :

\begin{tabular}{|c|c|c|c|}
\hline Authors & Date & Age & Location \\
\hline Vekshina & 1959 & Cretaceous & Siberia \\
\hline Bramlette and Martini & 1964 & Maastrichtian & $\begin{array}{c}\text { type of } \\
\text { Maastrichtian }\end{array}$ \\
\hline Gartner & 1968 & Maastrichtian & $\begin{array}{c}\text { Denmark, } \\
\text { France, Tunisia, } \\
\text { U.S.A. }\end{array}$ \\
\hline Perch-Nielsen & 1985 & $\begin{array}{c}\text { Campanian to } \\
\text { Maastrichtian }\end{array}$ & General \\
\hline $\begin{array}{c}\text { Wanderley and } \\
\text { Aguiar }\end{array}$ & 2006 & $\begin{array}{c}\text { Campanian to } \\
\text { Maastrichtian }\end{array}$ & Atlantic Ocean \\
\hline $\begin{array}{c}\text { Tantawy } \text { et al. } \\
\text { Campanian to } \\
\text { Maastrichtian }\end{array}$ & Egypt \\
\hline
\end{tabular}

Arkhangelskilla sp.

Pl. 1, Fig. 2

Description: Heterococcoliths, placolith coccoliths with central area spanned by axial crosses and grills, or filled by a perforate plate divided by axial sutures. The shields are typically bright in cross polarized light. 1-2 distal shield cycles; bright, unicycle LM image although darker towards outer edge.

Remarks: The central area and sutures are not clear, therefore the species left under open name.

\section{Occurrences :}

\begin{tabular}{|c|c|c|}
\hline Authors & Age & Location \\
\hline Present work & $\begin{array}{c}\text { Early } \\
\text { Maastrichtian }\end{array}$ & Iraq \\
& \\
\hline
\end{tabular}

Family Chiastozygaceae Rood, Hay and Barnard, 1973 Genus Chiastozygus Gartner, 1968

Type species : Zygodiscus amphipons Bramlette and Martini, 1964

\section{Chiastozygus sp.}

Pl. 1, Fig. 3

Description: Heterococcoliths, Loxoliths with variably-developed proximal/innercycles and a central-area spanned by diagonal cross bars. LM image includes unicyclic type.

Remarks: The species left under open due to the lack of material. 
Occurrences :

\begin{tabular}{|c|c|c|}
\hline Authors & Age & Location \\
\hline Present work & $\begin{array}{c}\text { Early } \\
\text { Maastrichtian }\end{array}$ & Iraq \\
\hline
\end{tabular}

Family Microrhabdulaceae Deflandre, 1963

Genus Lithraphidites Deflandre, 1963

Type species : Lithraphidites carniolensis Deflandre, 1963

Lithraphidites carniolensis Deflandre, 1963

Pl. 1, Fig. 5

1963 Lithraphidites carniolensis Deflandre; Seances Acad. Sci. Paris, 256, 3484-3486.

1968 Lithraphidites carniolensis Deflandre ,Gartner; Univ. Kans. Paleont. Contrib. P. 43, Pl. 5, Fig. 4.

1985 Lithraphidites carniolensis Deflandre, Perch-Nielsen ; Plankton Stratigraphy, P. 373.

Description: Nannoliths, Elongated rod-like with a cruciform or circular crosssection, which have expanded lateral blades, it is rods have four equal keels that run the whole length of the rods.

Occurrences :

\begin{tabular}{|c|c|c|c|}
\hline Authors & Date & Age & Location \\
\hline Deflandre & 1963 & Cretaceous & U.S.A. \\
\hline Bukry & 1969 & $\begin{array}{c}\text { Albian to } \\
\text { Maastrichtian }\end{array}$ & U.S.A. \\
\hline Perch-Nielsen & 1985 & $\begin{array}{c}\text { Berriasian to } \\
\text { Maastrichtian }\end{array}$ & General \\
\hline Tantawy et al. & 2001 & Maastrichtian & Egypt \\
\hline
\end{tabular}

\section{Lithraphidites sp.}

P1. 1, Fig. 6

Description: Nannoliths, Elongated rod-like with a cruciform or circular crosssection, which have expanded lateral blades.

Remarks: The present species differs from all other species in having rods at two ends, therfore left under open name.

Occurrences :

\begin{tabular}{|c|c|c|}
\hline Authors & Age & Location \\
\hline Present work & $\begin{array}{c}\text { Early } \\
\text { Maastrichtian }\end{array}$ & Iraq \\
\hline
\end{tabular}

Genus Microrhabdulus Deflandre, 1959

Type species : Microrhabdulus decoratus Deflandre, 1959

Microrhabdulus decoratus Deflandre,1959

Pl. 1, Fig. 7 
1959 Microrhabdulus decoratus Deflandre ; Micropaleont., 2, 127-52.

1985 Microrhabdulus decoratus Deflandre; Perch-Nielsen ; Plankton Stratigraphy, P. 374.

Description: Nannoliths, Elongated rod-like with a cruciform or circular crosssection, which generally taper at both ends, circular cross-section complex construction.

Occurrences :

\begin{tabular}{|c|c|c|c|}
\hline Authors & Date & Age & Location \\
\hline Deflandre & 1959 & $\begin{array}{c}\text { Santonian } \\
\text { through } \\
\text { Maastrichtian }\end{array}$ & U.S.A. \\
\hline Perch-Nielsen & 1985 & $\begin{array}{c}\text { Turonian to } \\
\text { Maastrichtian }\end{array}$ & General \\
\hline Tantawy et al. & 2001 & Maastrichtian & Egypt \\
\hline
\end{tabular}

Family Podrorhabdaceae Noel, 1965

Genus Cribrosphaerella Deflandre, 1952

Type species : Cribrosphaerella ehrenbergii ,Arkhengesky, 1912

\section{Cribrosphaerella ehrenbergii, Arkhengesky, 1912}

Pl. 1, Fig. 4

1912 Cribrosphaerella ehrenbergii Arkhengesky; Mater. Geol. Russl., Vol. 24, P. 412, P1. 6, Fig. 19-20.

1968 Cribrosphaerella ehrenbergii Arkhengesky; Gartner Univ. Kans. Paleont. Contrib. P. 40, P1. 1, Fig. 14-15.

1985 Cribrosphaerella ehrenbergii Arkhengesky; Perch-Nielsen ; Plankton Stratigraphy, P. 387.

Description: Heterococcoliths, Elliptical to circular placoliths with elliptical to subrectangular rim; multiperforate central-area net.

Occurrences :

\begin{tabular}{|c|c|c|c|}
\hline Authors & Date & Age & Location \\
\hline Arkhengesky & 1912 & $\begin{array}{c}\text { Upper } \\
\text { Cretaceous }\end{array}$ & Russia \\
\hline Bramlette and Martini & 1964 & Maastrichtian & $\begin{array}{c}\text { Type of } \\
\text { Maastrichtian }\end{array}$ \\
\hline $\begin{array}{c}\text { Gartner } \\
\text { Aguiar }\end{array}$ & 2006 & $\begin{array}{c}\text { Denmark, } \\
\text { France, Tunisia, } \\
\text { U.S.A. }\end{array}$ \\
\hline $\begin{array}{c}\text { Tantawy } \text { et al. } \\
\text { Maastrichtian }\end{array}$ & $\begin{array}{c}\text { Atlantic Ocean } \\
\text { Maastrichtian }\end{array}$ & Egypt \\
\hline
\end{tabular}


Genus Stradneria Reinhardt, 1964

\section{Stradneria crenulata Bramlette and Sullivan, 1964}

\section{P1. 1, Fig. 15}

1964 Stradneria crenulata Bramlette and Sullivan ; Micropaleontol, 7, 129-88.

1985 Stradneria crenulata Bramlette and Sullivan, Perch-Nielsen ; Plankton Stratigraphy, P. 386.

Description: Heterococcoliths, Placoliths with two shields and a central-area spanned by a variety of structures, most commonly fibrous axial cross bars with subsidiary lateral bars and a solid central spine or process; the elements are usually radial or near radial and do not appear to imbricate. LM image is moderately birefringent.

Occurrences :

\begin{tabular}{|c|c|c|c|}
\hline Authors & Date & Age & Location \\
\hline Perch-Nielsen & 1985 & $\begin{array}{c}\text { Upper } \\
\text { Cretaceous }\end{array}$ & General \\
\hline Tantawy et al. & 2001 & Maastrichtian & Egypt \\
\hline
\end{tabular}

Family Polycyclolithaceae Forchheimer, 1972

Genus Quadrum Princ and Perch-Nielsen, 1977

Type species: Quadrum gartneri Princ and Perch-Nielsen, 1977

\section{Quadrum cf. trifidum Stradner and Papp, 1961}

$$
\text { P1.1,Fig. } 10
$$

1961 Quadrum trifidum Stradner and Papp; Jahrb. geol. Bundesants. (Wien), 7, 1-159.

1985 Quadrum trifidum Stradner and Papp Perch-Nielsen ; Plankton Stratigraphy, P. 390.

Description: Nannoliths, Elements have tangential $c$-axis orientation, 3-5 ray-like wall-cycle elements, the elements are joined along sutures which go out to the midpoint of the cube edges, no central opening or diaphragm.

Occurrences :

\begin{tabular}{|c|c|c|c|}
\hline Authors & Date & Age & Location \\
\hline Stradner and Papp & 1961 & $\begin{array}{c}\text { Upper } \\
\text { Cretaceous }\end{array}$ & Italy \\
\hline Perch-Nielsen & 1985 & $\begin{array}{c}\text { Campanian to } \\
\text { Maastrichtian }\end{array}$ & General \\
\hline Tantawy et al. & 2001 & $\begin{array}{c}\text { Campanian to } \\
\text { Maastrichtian }\end{array}$ & Egypt \\
\hline
\end{tabular}


Family Prediscosphaeraceae Rood, Hay and Barnard, 1971

Genus Prediscosphaera Vekshina, 1959

Type species : Prediscosphaera decorate Vekshina, 1959

Prediscosphaera cretacea Arkhangelsky, 1912

Pl. 1, Fig. 8

1912 Prediscosphaera cretacea Arkhangesky; Mater. Geol. Russ., 25, 1- 631.

1985 Prediscosphaera cretacea Arkhangesky, Perch-Nielsen ; Plankton Stratigraphy, p. 394.

Description: Heterococcoliths, Elliptical to circular placoliths with two shields and a central-area spanned by cross bars which support tall. The distal shield is typically bicyclic, with a broad outer cycle, The LM image is bicyclic, with the outer cycle dark, and inner cycle bright.

Occurrences :

\begin{tabular}{|c|c|c|c|}
\hline Authors & Date & Age & Location \\
\hline Arkhangesky & 1912 & $\begin{array}{c}\text { upper } \\
\text { Cretaceous }\end{array}$ & Russia \\
\hline Gartner & 1968 & $\begin{array}{c}\text { Campanian to } \\
\text { Maastrichtian }\end{array}$ & U.S.A. \\
\hline Donnaly & 1989 & $\begin{array}{c}\text { Upper } \\
\text { Cretaceous }\end{array}$ & Greenland \\
\hline
\end{tabular}

\section{Prediscosphaera grandis Perch-Nielsen, 1979}

Pl. 1, Fig. 9

1979 Prediscosphaera grandis Perch-Nielsen; IUGS Series A, 6, 223-72.

1985 Prediscosphaera grandis Perch-Nielsen Perch-Nielsen; Plankton Stratigraphy, p. 394.

Description: Heterococcoliths, Elliptical to circular placoliths with two shields and a central-area spanned by cross bars which support tall. The distal shield is typically bicyclic, with a broad outer cycle, The LM image is bicyclic, with the outer cycle dark, and inner cycle bright. very close to the species above but small and more cyclical.

Occurrences :

\begin{tabular}{|c|c|c|c|}
\hline Authors & Date & Age & Location \\
\hline Perch-Nielsen & 1979 & Maastrichtian & Italy \\
\hline Perch-Nielsen & 1985 & Maastrichtian & General \\
\hline
\end{tabular}

Family Rhagodiscaeae Hay, 1977

Genus Rhagodiscus Reinhardt, 1967

Rhagodiscus angustus Stradner, 1963

Pl. 1, Fig. 13 
1963 Rhagodiscus angustus Stradner ; Proc. Petro. Set. 1, 1-16.

1985 Rhagodiscus angustus Stradner, Perch-Nielsen ; Plankton Stratigraphy, P. 394.

Description: Heterococcliths, Loxoliths with a dominant distal/outer-cycle and a central-area typically filled by a plate of granular calcite. The central structure may be spine-bearing, perforate or massive. The LM image is generally unicyclic.

Occurrences :

\begin{tabular}{|c|c|c|c|}
\hline Authors & Date & Age & Location \\
\hline Stradner & 1963 & $\begin{array}{c}\text { Upper } \\
\text { Cretaceous }\end{array}$ & Germany \\
\hline Perch-Nielsen & 1985 & $\begin{array}{c}\text { Aptian to } \\
\text { Maastrichtian }\end{array}$ & General \\
\hline Tantawy et al. & 2001 & $\begin{array}{c}\text { Campanian to } \\
\text { Maastrichtian }\end{array}$ & Egypt \\
\hline
\end{tabular}

\section{Rhagodiscus sp.}

Pl. 1, Fig. 14

Description: Heterococcliths, Loxoliths with a dominant distal/outer-cycle and a central-area typically filled by a plate of granular calcite. The central structure may be spine-bearing, perforate or massive. The LM image is generally unicyclic.

Remarks: Central area is not clear, Therefore left under open name.

Occurrences :

\begin{tabular}{|c|c|c|}
\hline Authors & Age & Location \\
\hline Present work & $\begin{array}{c}\text { Early } \\
\text { Maastrichtian }\end{array}$ & Iraq \\
\hline
\end{tabular}

Family Zygodiscaceae Hay and Mohler, 1967

Genus Reinhardites Perch-Nielsen, 1968

\section{Reinhardites levis Sissingh, 1977}

Pl. 1, Fig. 10

1985 Reinhardites levis Sissingh Perch-Nielsen ; Plankton Stratigraphy, p. 407.

Description: Heterococcoliths, Loxoliths with variably-developed proximal/innercycles and a central-area spanned by a single transverse bar. LM image includes both unicyclic, very broad rim, with narrow central-area spanned/filled by a bar.

Occurrences :

\begin{tabular}{|c|c|c|c|}
\hline Authors & Date & Age & Location \\
\hline Perch-Nielsen & 1985 & $\begin{array}{c}\text { Campanian to } \\
\text { Maastrichtian }\end{array}$ & General \\
\hline Tantawy et al. & 2001 & Maastrichtian & Egypt \\
\hline
\end{tabular}




\section{Reinhardites sp.}

Pl. 1, Fig. 11

Description: Heterococcoliths, Loxoliths with variably-developed proximal/innercycles and a central-area spanned by a single transverse bar. LM image includes both unicyclic, very broad rim, with narrow central-area spanned/filled by a bar.

Remarks: The species very closed to Reinhardites levis Sissingh,1977 but smaller in size and due to the lack of material the present species left under open name.

\section{Occurrences :}

\begin{tabular}{|c|c|c|}
\hline Authors & Age & Location \\
\hline Present work & $\begin{array}{c}\text { Early } \\
\text { Maastrichtian }\end{array}$ & Iraq \\
\hline
\end{tabular}

Genus Tranolithus Stover, 1966

\section{Tranolithus phacelosus Stover, 1966}

Pl. 1, Fig. 16

1966 Tranolithus phacelosus Stover; Micropaleontol. 12, 133 - 67.

1985 Tranolithus phacelosus Stover Perch-Nielsen; Plankton Stratigraphy, p. 408.

Description: Heterococcoliths, Loxoliths with variably-developed proximal/innercycles and a central-area spanned by a single transverse bar. LM image includes both unicyclic and bicyclic types. central-area spanned by 2-4 broad, disjunct platelets constitute a transverse bar, and there is a proximal net of lateral bars.

Occurrences :

\begin{tabular}{|c|c|c|c|}
\hline Authors & Date & Age & Location \\
\hline Stover & 1966 & $\begin{array}{c}\text { Upper } \\
\text { Cretaceous }\end{array}$ & France \\
\hline Perch-Nielsen & 1985 & $\begin{array}{c}\text { Albian to } \\
\text { Maastrichtian }\end{array}$ & General \\
\hline
\end{tabular}

\section{Nannobiostratigraphy}

Sixteen species of calcareous nannofossils were identified, depending on the stratigraphic distribution of the recorded species (Fig. 2), the two following biozones are identified: 


\section{1-Tranolithus phacelosus Interval Biozone(CC23b)}

Definition: Interval from Last occurrence of Reinhardites anthrophorus (Defandre,1959) to Last occurrence of Tranolithus phacelosus Stover (1966). Thickness: Lower ( 30 ) meters consist of marly limestone.

Boundaries: The lower boundary of this biozone not included in the studied section, The upper boundary is marked by the last occurrence of Tranolithus phacelosus Stover (1966).

Discussion: This biozone correlated with Tranolithus phacelosus (CC23) by Perch-Nielsen (1979) and Sissingh (1977) aged Late Campanian to Early Maastrichtian, and correlated with Quadrum tifidum by Doeven (1983). aged Early Maastrichtian, and correlated with Tetralithus trifidus by Roth (1978). The Aspidolithus parcus subdivided the biozone CC23 into CC23a and CC23b, according to Sissingh (1977) which disappear in this section, therefore this Biozone aged Early Maastrichtian (Fig. 3).

\section{2- Reinhardites levis Interval Biozone(CC24)}

Definition: Interval from Last occurrence of Tranolithus phacelosus Stover (1966) to Last occurrence of Renhardites levis (Sissingh, 1977).

Thickness: Upper ( 15 ) meters consist of marly limestone.

Boundaries: The lower Boundary is marked by last occurrence of Tranolithus phacelosus Stover (1966), and the upper boundary is not included in the studied section.

Discussion: This biozone correlated with Renhardites levis (CC24) by PerchNielsen (1979) and Sissingh (1977) aged Early Maastrichtian, and correlated with Arkhangeskilla cymbiformis by Doeven (1983) aged Early Maastrichtian, and correlated with Lithraphidites praequardatus by Roth (1978). Therefore this biozone aged Early Maastrichtian. 


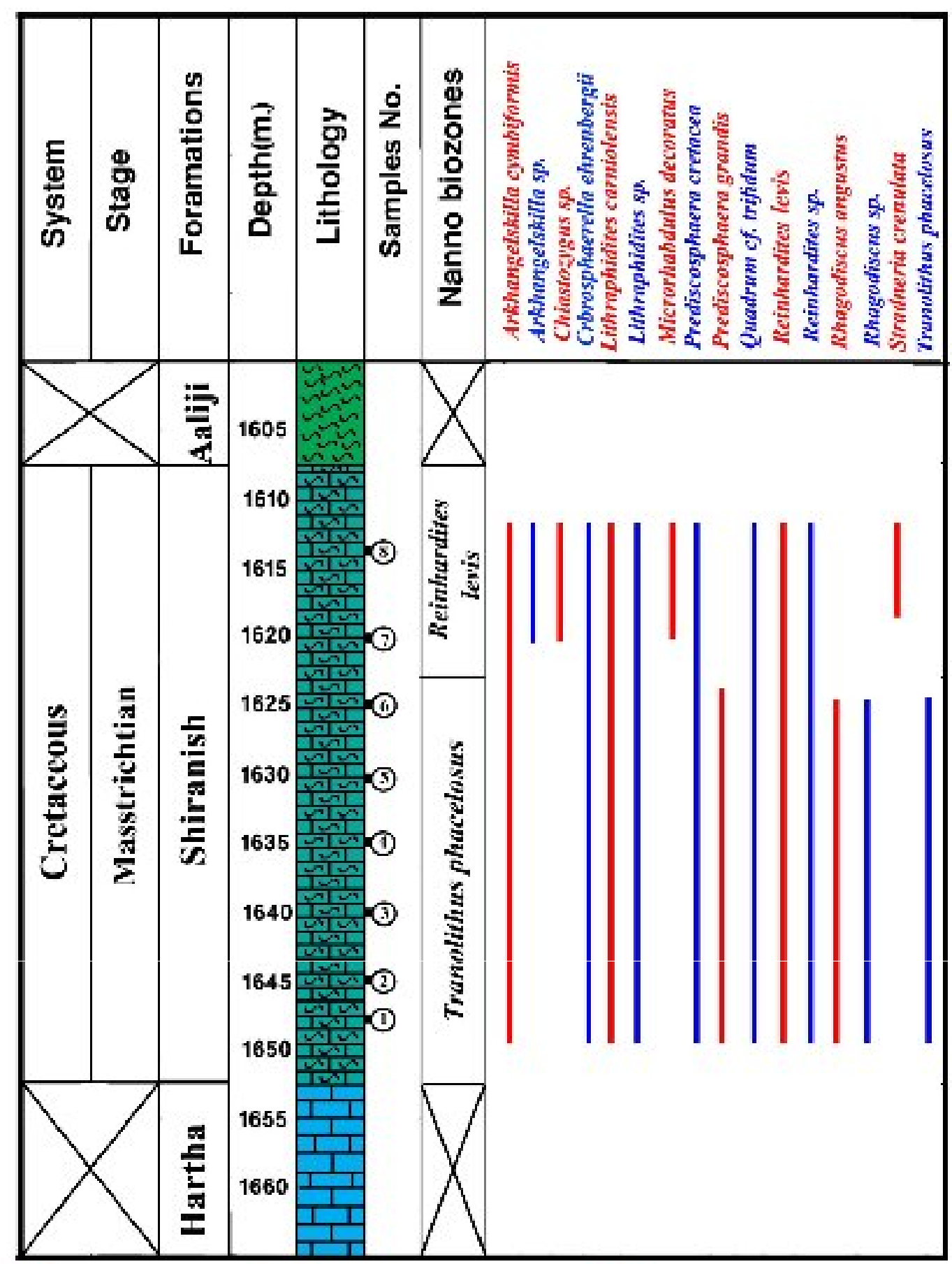

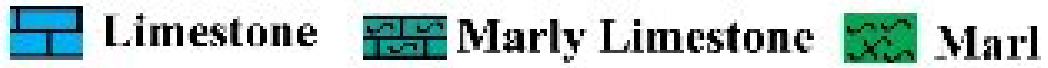

$\square$ Not studied

Fig. 2: Stratigraphic Distribution of Calcareous nannofossils. 
Nannobiostratigrphy of Shiranish Formation in Balad

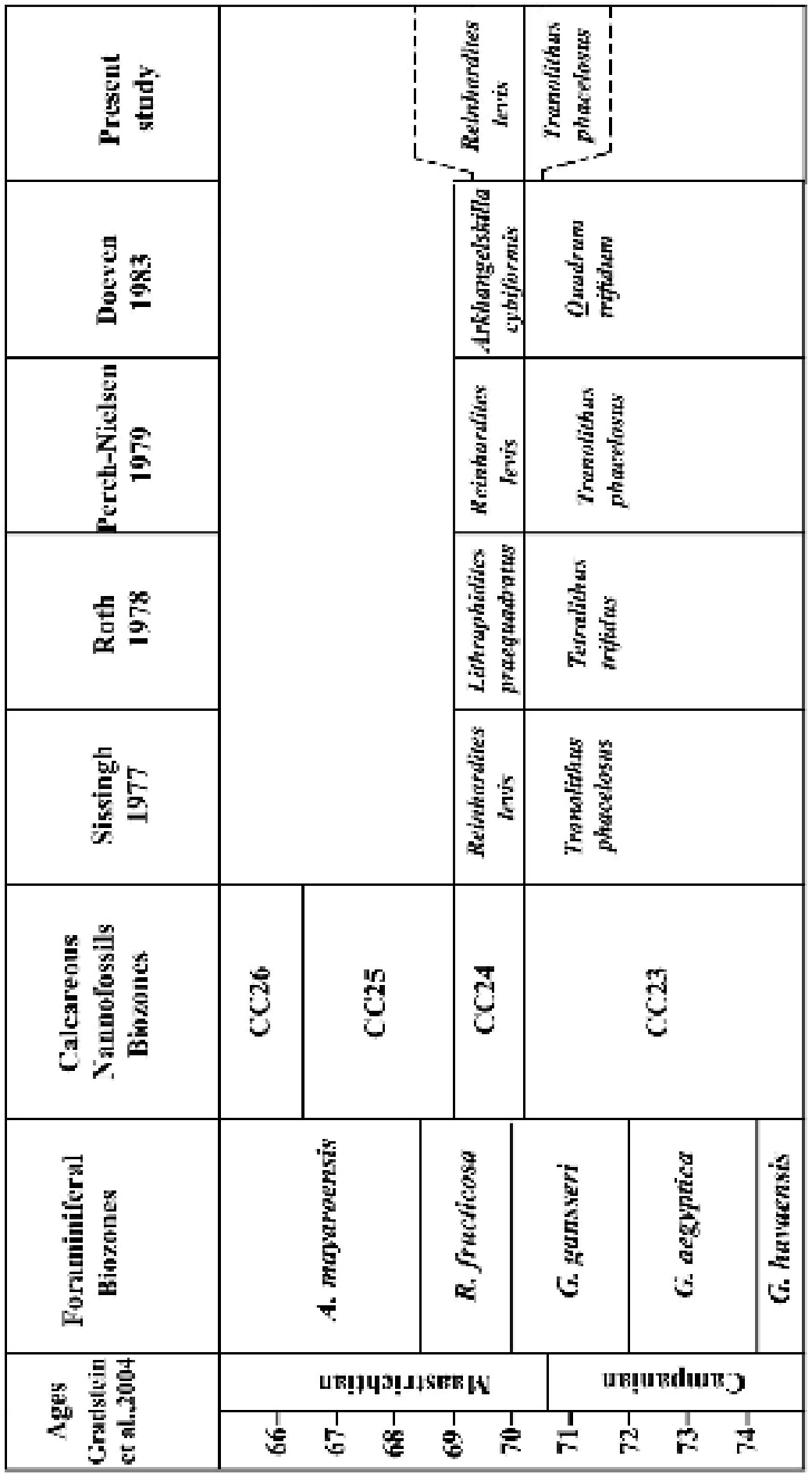

Fig. 3: Correlated Chart for Present Work with Regional Studies. 


\section{ACKNOWLEDGMENT}

We would like to express our thanks to Dr. Ibrahim Younis Al-Shareefi / Dept. of Geology/Science College/Mosul University who Provided us the samples of the present study.

\section{REFERENCES}

Arkhangelsky, A. D., 1912. Upper Cretaceous Deposits of East European Russia. Mater. Geol. Russ., Vol. 25, pp. 1 - 613.

Bellen, R. C. van., Dunnington, H. V., Wetzel, R. and Morton, D. M., 1959. Lexique Stratigraphic International, V. III, Asie, Fasc. 10 a, Iraq. 333p.

Bramlette, M. N. and Martini, E., 1964. The Great Change in Calcareous Nannoplankton Fossils between the Maestrichtian and Danian. Micropaleontology, Vol. 10, pp. 291 - 322.

Bramlette, M. N. and Sullivan, F. R., 1961. Coccolithophorids and Related pp. $129-188,14$ Pls. 1, Text - Fig.

Buday, R. T. ,1980. The Regional Geology of Iraq 1, Stratigraphy and Paleogeography, Kassab, I. I. M. and Jassim, S. Z. (ed.), SOM, Baghdad., $445 \mathrm{p}$.

Bukry, D., 1969. Upper Cretaceous Coccoliths from Texas and Europe. Univ. Kans. Paleont. Contrib., Protista,art. Vol. 51, pp.1 - 79.

Deflandre, G., 1959. Sur les Nannofossils Calcaires et leur Systematique. Rev. Micropalaeontology, Vol. 2, pp. 127 - 52.

Deflandre, G., 1963. Sur les Microrhabdulides, Famille Nnovella de Nannofossiles cacires. C. r. Seances Acad. Sci. Paris, Vol. 256, pp. 3484-3486.

Doeven, P. H., 1983. Cretaceous Nannofossils Stratigraphy and Paleoecology of Canadian Atlantic Margin. In Bolli, H. M., Saundes, J. B., and Perch-Nielsen, K.(eds.),1985, Plankton stratigraphy. Cambridge University Press, Cambridge, pp. 329 - 426.

Donnaly, D. M., 1989. Calcareous Nannofossils of the Norwegian-Greenland Sea: ODP Leg 104.PODP, Science Results, Vol. 104, pp. 459 - 486.

Gartner, S., 1968. Coccoliths and related calcareous Nnannofossils from Upper Cretaceous Deposits of Texas and Arkansas .Univ. Kans. Paleont. Contrib., Protista, art. 1, pp. 1 - 56.

Gradstein, F. M., Ogg, J. G., Smith, L. J., 2004. A new Geologic Time Scale, with Special Reference to Precambrian and Neogene. Episodes, Articles, Vol. 27, No. 2, pp. 83 - 100.

Perch-Nielsen, K. 1985. Mesozoic Calcareous Nannofossils. In Bolli, H. M., Saundes, J. B., and Perch-Nielsen, K.(eds.), Plankton Stratigraphy.Cambridge University Press,Cambridge, pp. 427 - 554.

Perch-Nielsen, K, 1979. Calcareous Nannofossils from the Cretaceous between the North Sea and the Mediterranean. In Bolli, H. M., Saunders, J. B., and Perch-Nielsen, K. (eds.), 1985, Plankton Stratigraphy. Cambridge University Press, Cambridge, pp. 329 - 426. 
Roth, P. H.,1978. Cretaceous Nannoplankton Biostratigraphy and Oceanography of the Northwestern Atlantic Ocean. In Bolli, H. M., Saunders, J. B., and Perch-Nielsen, K. (eds.), 1985. Plankton Stratigraphy. Cambridge University Press, Cambridge, pp. 329 - 426.

Sissingh, W, 1977. Biostratigraphy of Cretaceous Calcareous Nannoplankton. In Bolli, H. M., Saundes, J. B., and Perch-Nielsen, K. (eds.),1985. Plankton Stratigraphy. Cambridge University Press, Cambridge, pp. 329 - 426.

Stover, L. E., 1966. Cretaceous Coccoliths and Associated Nannofosils from France and the Nether land. Micropalaeontology, Vol. 12, pp. 133 - 167.

Stradner, H., 1963. New Contribution to Mesozoic Stratigraphy by Means of Nannofossils. Proceeding of the $6^{\text {th }}$ World Petrol. Congr. Sect. 1, paper

Tantawy, A. A., Keller, G., Adatte, T., Stinnesbeck, W. and Kassab, A., 2001. Maastrichtian to Paleocene Depositional Environment of the Dekhla Formation,Western Desert, Egypt: Sedimentology, Minerology, and Integrated Micro-and Macrofossil Biostratigraphies. Cretaceous Researches Vol. 22, pp. $795-827$.

Vekshina, V. N., 1959. Coccolithophoridae of the Maastrichtian Deposits of the west Siberian lowlands. SNIIGGIMS, Vol. 2, pp. 56 - 77.

Wanderley, M. D. and Aguiar, R. P., 2006. Calcareous Nannofossils from Cretaceous / Paleogene Boundary and Earliest Danian of Santo Basin (SAO Palulo Plateu,Brazil)-ODP Leg 39 -Site 356-cores 28 / 29. Geociencas, Vol. 25, pp. 389 - 401.

\section{Plate 1}

1 Arkhangelskilla cymbiformis Vekshina (1959)

2 Arkhangelskilla sp.

3 Chiastozygus sp.

4 Cribrosphearella ehrenbergii (Arkhengesky, 1912)

5 Lithraphidites carniolensis Deflandre (1963)

6 Lithraphidites sp.

7 Microrhabdulus decoratus Deflandre (1959)

8 Prediscosphaera cretacea (Arkhangesky, 1912)

9 Prediscosphaera grandis Perch-Nielsen (1979)

10 Quadrum cf. trifidum (Stradner and Papp, 1961)

11 Reinhardites levis (Sissingh, 1977)

12 Reinhardites sp.

13 Rhagodiscus angustus (Stradner, 1963)

14 Rhagodiscus sp.

15 Stradneria crenulata (Bramlette and Sullivan, 1964)

16 Tranolithus phacelosus Stover (1966) 


\section{Plate 1}

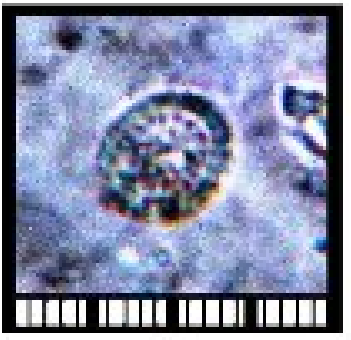

1

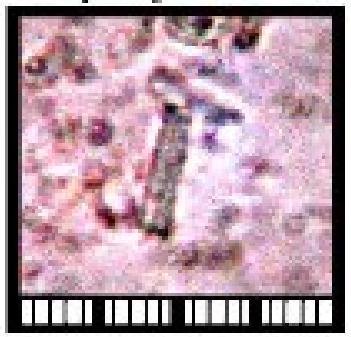

5

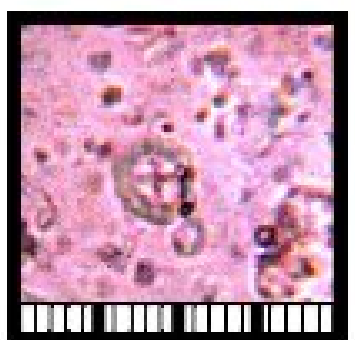

9

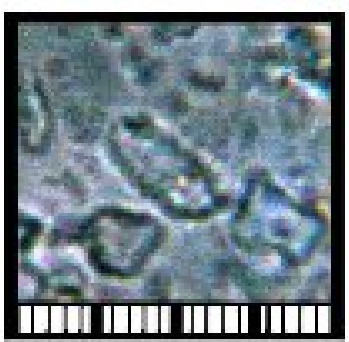

13

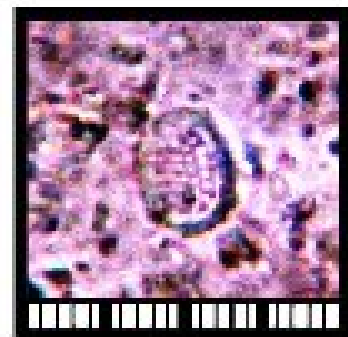

2

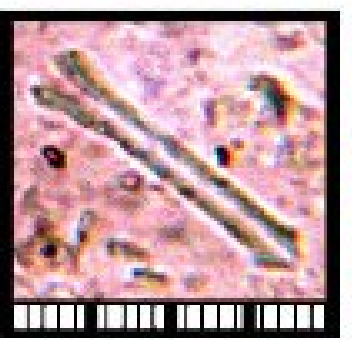

6

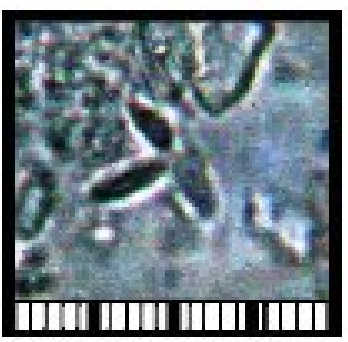

10

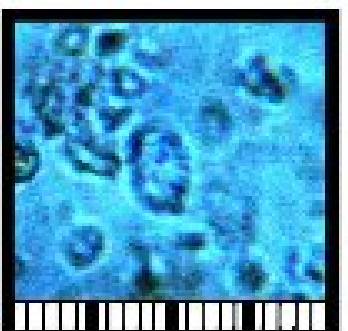

14

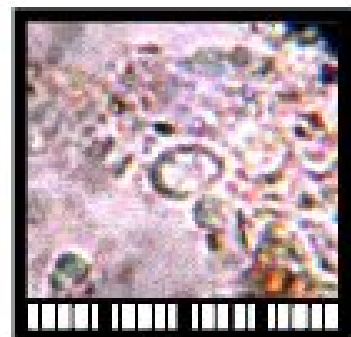

3

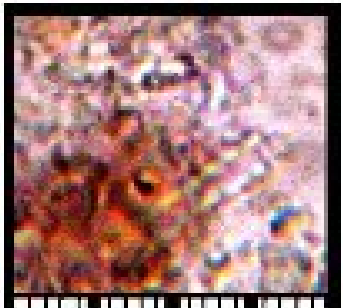

7

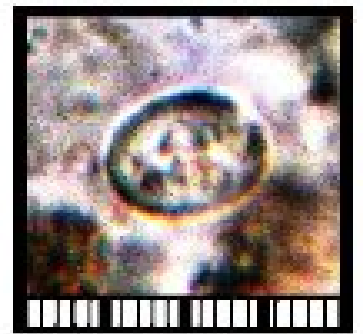

11

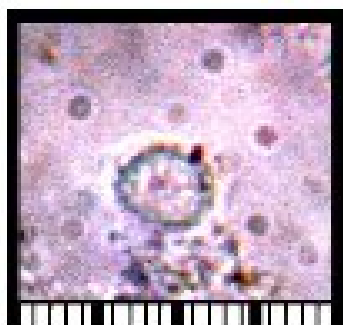

15

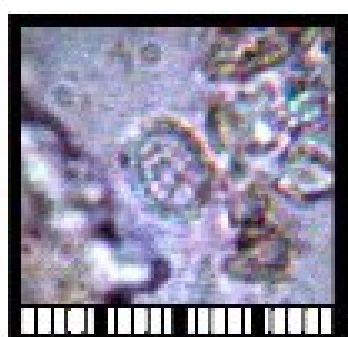

4

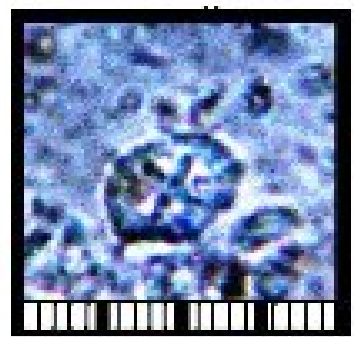

8

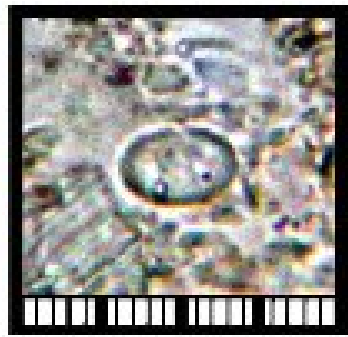

12

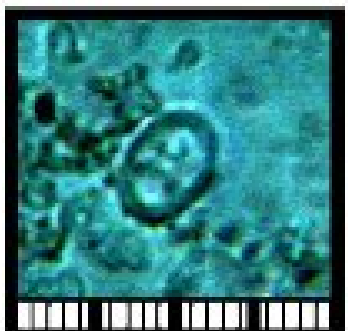

16

ШUI 5 micron 